\title{
A tentative Study on Implementation of Stock Options Plan for Enterprise Staff
}

\author{
Xingmei Fu \\ Department of Air Transportation Management, Civil Aviation Flight University of China, \\ Guanghan, 618300, China
}

Keywords: Enterprise. Employees. Stock options plan

\begin{abstract}
The stock potions plan is an important component in the incentive system existed now, and it has been popularization and application in many western countries. However, this plan's mass appeal has yet to be established. To this end, in this article, incentive function and validation method of stock options would be analyzed, design and technical structure of enterprise employee's stock options plan shall be discussed, and promotion campaign of stock options in our country will be elaborated.
\end{abstract}

\section{Introduction}

Key employees are always great demands in talent markets with short supply, and imbalance once shown in this type of talent between supply and demand, the cost and talent flow rate would be all-time high. Therefore, in order to keep the talent based and away from brain drain, stock options incentive system would be considered. Stock options plan switch traditional employment mode into coexistence of interests of enterprise and employees, tie enterprise and employees up to prevent short-period of the employees with great power, especially on retain the talent. Yet to effect of policy environment of our country and improper operation of some enterprises, the implementation of stock options plan is unsatisfactory, so a further study shall be taken to improve it.

\section{Stock options play an important role in staff incentive.}

Long-term incentive compensation has been accepted by more and more enterprises in the occident recently to attract and retain key employees for tight coupling of employees' working achievements and enterprise long-term development strategy. One of the main content of long-term incentive compensation is stock options plan that means an employee could purchase appropriate amount of the enterprise stock at a fixed rate in a certain year and sell at a reasonable price. It thus appears that stock options plan is an extraordinary power of key employees given by enterprises, which can be used to purchase their own enterprise stocks at stock options price within the stipulated time. This purchasing process is called exercise. Holder of stock options has no cash earnings before his exercise; the person can only get price difference between exercise price and market price on the exercise day after his exercise. The employee of enterprise shall have the right to determine when to sell his stock after his exercise. In the mean time, the important role of stock options plan as long-term incentive compensation management can not only be reflected in a single plan implantation, but also various its form and content with enterprise incentive implementation and requirements of talent attraction. At the end of a stock option, a new plan shall be launched to retain key employees in the enterprise and play a maximum positive role.

Stock options plan plays an important incentive role in two aspects, and first one is rewards. Enterprises which launched stock options would have their stock price rise when they productive operated, as in the following, employees could exercise their stock options right to purchase appropriate amount of stocks at stipulated low price, and to get large sums of cash after selling. But, if the production and operation failed to meet requirements, the share would drop. Key employees would have to give up their stock options right for there would be less benefit. As an important component in the incentive system, benefits gained from stock options could be much higher than 
their annual salary, as well as the motivation. Second one is enterprise ownership. As long as the employee exercised his stock options right successfully, he becomes a shareholder of the enterprise, which means that he is the owner of the enterprise. Naturally, he would pay much more attention on further development of the enterprise. Hence, great incentive effect on key employees has been made before and after his exercise. More than half of enterprises in U.S. have implemented stock options plan at present including 90\% of Top 500. In recent years, enterprises in our country have been progressively concern about stock options plan, and start to carry it out.

\section{Validation method of employees' stock options.}

Validation of employees' stock options has two major issues: firstly, shall it be listed in equity column or liabilities column under balance sheet; secondly, shall it be verified as expense or component of profit distribution. One of accounting recognition basic principles is to ensure items meet the specification made by related accounting elements. That is to say, each verified item has to be able to be reflected on essential of economy. Stock option is not only a long-term incentive system, but also a product of innovation management system implemented, as well as one of option contracts. There is no difference between essence of option contract and salary. According to the definition, liabilities are created by previous transactions or other items, which do not work on stock options. Exercise of stock options depends on future stock price and exercise price without capital outflow. Instead of performing its obligation through paying assets and offering services, stock option shall be exercised by stock issue, and that's the reason why it cannot be listed in liabilities column under balance sheet. Equity defined as the balance of assets after deducting all liabilities. However, stock option fails to meet the definition of equity, and there is no balance of assets before exercise. Therefore, stock option is neither liabilities nor equity, but it is necessary to list it in existed accounting elements for validation and calculation.

As for the second issue, there are two different views: expense and profit distribution. The former takes stock options as salary, while the latter considers the essential of economy of stock options as a sharing of residual claims where employees involved, and it shall be treated as part of profit distribution. To my opinion, the view of expense could reflect the essential of stock options more clearly. Since the essential of stock options given by enterprise is benefit transfer and compensation for services provided by employees, in accordance with matching principle, cost compensation shall be considered as expense, however, once the expense cannot be realized, inflated profits would be created to make stock price beyond its actual value and disorder efficiency of resource allocation in the open market.

\section{Design and technical structure of stock options plan.}

\section{Design of stock options plan}

Compensation committee shall be established to be responsible for decisions on stock options issues. Every year, compensation committee shall determine the person to be granted with stock options, and the amount, timing, as well as other related issues.

\section{Technical structure of stock options plan}

1). Clear stock source. The original major shareholders shall transfer part of their shares or add holdings - newly issued shares. Although enterprises could repurchase their own shares from secondary market, this method is hard to be put in practice, for Company Law of our country states that invalid.

2). Clear exercise price. Generally the price is fair market value of the date employee granted. E.g.: Hong Kong Listing Rules stipulates that price of stock option shall not be lower than $80 \%$ of five trading days average close price before the day granted.

3). Clear the amount. As the amount to be granted shall be related to the employee's work performance, so it is important to establish a scientific and regular performance appraising system, and each enterprise could have its own system. Normally financial indexes like return of each share 
and net assets return ratio are common standards to determine the amount to be granted. Methods such as historical data comparison and return rates of the same industry comparison are used in assessment of return per share, net assets returns ratio, etc. financial indexes to conduct comprehensive evaluation.

4). Clear the exercise schedule. Currently the duration of exercise schedule defined is always less than ten years, however, some other enterprises even make it three to six years. Specific years of the duration shall be defined depending on the enterprise's actual condition.

5). Clear stock option approval concrete proposal of shareholders meeting. Stock Option Plan Agreement shall be signed between the enterprise and employees to be granted.

\section{Countermeasure of promotion.}

\section{Relative preparation works shall be done actively to coordinate stock option plan for employees.}

First of all, essential revision of Securities Law and other reference laws and administrative regulations formulated for the supervision and administration of securities market shall be conducted to legalize stock options plan for employees. Secondly, national specifications of stock options for employees shall be made as soon as possible, including subject to be granted, object to be implemented, amount and price shall be exercised, shortest duration of exercise schedule, minimum retention rate and processing scheme of particular circumstances, etc. Thirdly, qualification examination shall be taken for implementation of stock options plan in listed companies. The implementation shall be taken as a trial in listed companies with better shareholding systems and well organized, rather than burst in swarms. The chosen companies shall be free from major events of breaching the principles and can grow well with development potential. Fourthly, legal norm shall be improved, including supervision, information disclosure and taxes, especially strict requirements shall be made to disclose stock-ownership and salary of executives in listed companies. At the same time, the supervisions of social independent agencies like law firms, accounting firms and assets evaluation organization shall be enhanced.

The following shall note in specific operations of stock options plan implementation

1). Implementation of stock options plan shall be suitable for the actual situation of China. Most of listed companies in our country are state-owned enterprises, with the purposes of hedging state assets and appreciation. To this end, defined appropriate amount of shares shall take effective employees motivation as a main principle without capital outflow.

2). Share source problems could be solved by issuing additional shares to executives, which spared could be issued to key employees who have achieved operation objectives.

3). Related accounting systems shall be improved. The stock options plan is established on the foundation of a series of financial data, which shall be accurate and complete.

4). Inside administration system shall be improved to make sure the protection of shareholders' equity.

5). Actively cultivate an effective and stable capital market to make the stock price reflect true information related to production and operation of enterprises and working effectiveness of managers.

6). Issues related to stock options plan shall be handled properly. Average salaries of executives in U.S. are 400 times of general workers'. Even through there are income differences in our country at present, with promotion of stock options plan, the differences between executives and general workers would be up to dozens of times. Stock options plan is an effective measure to be taken to motivate executives. However, the feeling of antipathy would arise from common workers when excessive income gap created, and their working passion would be bruised to dim the long-term development of the enterprise. Therefore, in order to make enterprises more dynamic, psychological enduring of employees and reasonable stock options plan shall be considered to motivate managers. 


\section{Conclusion}

In a word, the stock options plan for employees is sure to be widely applied in our country. However, when we cheer up for it, the actual conditions of our country shall be born in mind, so that the plan could be made more feasibility and operability. We also need to maintain vigilance against follow-on related questions to figure them out with incessant exploration and practice. Only by this way the stock options plan would not run off the purpose set when it created, and play an important role in the promotion of economic development in our country.

\section{References}

[1] Zhang Qian, Analysis in incentive effects of stock options plan for senior executive in our country, Scientific and Technological Information Development and Economy, 2010 (7).

[2] Li Xiaoyong, Study of issues on exercise schedule of stock options in China enterprises, Economics and Management, 2011 (4).

[3] Chen zhongwei,Brief talk on application of stock options incentive in state-owned enterprises, Foreign Investment in China, 2012 (11).

[4] Gao Jianpu, Analysis in feasibility of stock options plan for employees, China Business \& Trade, 2013 (7).

[5] Gou Ting, Countermeasures study and issues on stock options incentive of state-owned enterprises, Manager Journal, 2013 (18) 